\title{
HUBUNGAN EKSPRESI PENUANGAN TARI BEDHAYA DENGAN KOREOGRAFI BEDHAYASARPARODRA SUSUNAN SARYUNI PADMININGSIH
}

\author{
Ryndhu Puspita Lokanantasari \\ Program Pascasarjana \\ Institut Seni Indonesia Surakarta \\ Jl. Ki Hadjar Dewantara No. 19 Kentingan, Jebres, Surakarta, 57126 \\ Slamet \\ ISI Surakarta
}

\begin{abstract}
ABSTRAK
Tari Bedhaya Sarpa Rodra merupakan karya tari model bedhaya yang diciptakan di luar istana. Tari ini menggambarkan keserakahan manusia yang diwujudkan pada tokoh Sarpakenaka. Sajian koreografinya menghadirkan keunikan terutama pada gerak dan musik tarinya. Untuk itu, perlu dianalisis bentuk tari bedhaya dan proses pembentukan koreografinya dengan pisau analisis konsep bentuk Suzanne K. Langer, konsep Hastasawanda, dan teori Effortshape, serta aspek koreografi kelompok Y. Sumandiyo Hadi.
\end{abstract}

Kata kunci: bedhaya, Bedhaya Sarpa Rodra.

\begin{abstract}
The dance Bedhaya Sarpa Rodra is a dance work of bedhaya model created outside the palace. The dance shows human greedmanifested in the figureSarpakenaka. The choreography presents uniqueness especially on the movement and the dance music. For the reason, the form of dance Bedhaya and the composing process of choreography need to be analyzed by the concept of form by Suzanne K. Langer, concept of Hastasawanda, and Effortshape theory, as well as aspect of group choreography by Y. Sumandiyo Hadi.
\end{abstract}

Keywords: Bedhaya, Bedhaya Sarpa Rodra.

\section{A. Pengantar}

Tari Bedhaya Sarpa Rodra merupakan salah satu karya tari model bedhaya yang diciptakan di luar istana. Tari Bedhaya Sarpa Rodra disusun oleh Saryuni Padminingsih pada tahun 2007 dan dipentaskan di Teater Kecil Institut Seni Indonesia Surakarta. Tari Bedhaya Sarpa Rodra ditarikan oleh tujuh penari putri dengan menggunakan rias paes dan busana dodot. Struktur sajiannya terbagi menjadi tiga bagian yaitu maju beksan, beksan, dan mundur beksan. Musik tarinya menggunakan gamelan Jawa yang dipadukan dengan gamelan Bali dan beberapa alat musik lainnya seperti jimbe, bedug, terbang, kenthongan, dan biola.

Sajian tari Bedhaya Sarpa Rodra berbeda dengan tari bedhaya tradisi yang masih kental dengan kaidah tari bedhaya di istana seperti pada penggunaan gerak yang cepat, kuat, kasar, rowa (besar) pada bagian tertentu, gerak-gerak sensual menggoyangkan pinggul, menggetarkan bahu, dan gerak-gerak badan yang meliuk-liuk, adanya ketidakterikatan ragam gerak antar penari dan keajegan irama baik ritme atau temponya. Selain itu, penari juga memperlihatkan adanya pengkarakteran tokoh melalui ekspresi tubuh maupun ekspresi wajahnya. Hal ini jarang ditemukan pada karya tari model bedhaya lainnya.

Begitu juga dengan mendengar musik tarinya, pada bagian vokal menggunakan syair dengan dua bahasa yaitu bahasa Jawa dan Indonesia, adanya sebuah percakapan yang dilakukan oleh pemain musik dan terdapat bagian tertentu yang tidak menghadirkan tabuhan musik atau dapat dikatakan musiknya berhenti sementara, bagian tertentu tidak seirama dengan sajian gerak tarinya. Artinya ada pengkontrasan irama di antara keduanya. Seperti pada bagian tengah sajian, menampilkan gerak- gerak yang energik tetapi alat musik tidak dimainkan melainkan adanya percakapan antara pemusik. Menuju akhir sajian juga ditampilkan irama musik yang cepat sedangkan penari bergerak dengan irama pelan yang ajeg. 


\section{GEELR Jumal sori buatsa}

Penyusunan tari Bedhaya Sarpa Rodra ini merupakan wujud keberanian dalam penggarapan karya tari model bedhaya dengan menghadirkan kebaruan-kebaruan dari aspek koreografinya sehingga memiliki bentuk sajian yang berbeda dengan tari bedhaya tradisi pada umumnya. Namun, bila dilihat dari bentuk penyajiannya, apakah tari Bedhaya Sarpa Rodra ini termasuk ke dalam ranah bedhaya? Hal ini menjadi penting bagi peneliti untuk melakukan sebuah analisis pada tari Bedhaya Sarpa Rodra ini. Pokok permasalahan pada penelitian ini adalah mengapa karya tari Bedhaya Sarpa Rodra menggunakan nama "bedhaya" mengingat bahwa dilihat dari bentuk sajian koreografinya terdapat unsur-unsur baru yang dianggap tidak mencirikan bentuk tari bedhaya tradisi.

Penelitian ini mengarah pada bentuk koreografi tari Bedhaya Sarpa Rodra, sehingga menggunakan metode penelitian deskriptif analitik interpretatif dengan beberapa pendekatan analisis seperti konsep bentuk Suzanne K. Langer untuk menganalisis bentuk tari bedhaya, teori Effortshape untuk menganalisis proses pembentukan koreografi tari Bedhaya Sarpa Rodra, konsep Hastasawanda untuk menganalisis teknik gerak, dan aspek-aspek koreografi kelompok untuk menguraikan aspek koreografi Bedhaya Sarpa Rodra.

\section{B. Bentuk Tari Bedhaya}

Bedhaya identik dengan nama sebuah bentuk tari. Namun, istilah bedhaya memiliki pengertian yang lain seperti penari wanita istana, magang priyantun atau abdi dalem priyantun yaitu kelompok penari wanita di istana (Suharti, 2000:299). Bedhaya sebagai bentuk tari diungkapkan oleh K.P.H. Brongtodiningrat, salah satu empu tari Jawa Gaya Yogyakarta yang menyatakan bahwa bedhaya merupakan bentuk tari istana yang lazimnya ditarikan oleh sembilan penari putri (Suharti, 2015:98).

Dalam Serat Wedhapradangga menyatakan bahwa bedhaya sebagai jajar-jajar sarwi beksa sarta tinabuhan Gangsa Lokananta (gendhing kemanak), binarung ing kidung sekar utawi sekar ageng (R.Ng.Prajapangrawit, 1990:5). Artinya menari dalam posisi berbaris dengan diiringi oleh Gamelan Lokananta (gendhing kemanak) dibarengi dengan puisi metris sekar kawi atau sekar ageng (Prabowo, 2007:39-40). Serat Pustaka Raja juga menuliskan bahwa bedhaya ialah jajar-jajar sarwi beksa sarta tinabuhan kidung yang artinya menari dalam posisi berbaris serta dengan iringan kidung (nyanyian Jawa) (Prabowo, 2007:40). Pernyataan keduanya menandakan bahwa bedhaya sebagai bentuk tari memiliki tiga unsur yang saling melengkapi yaitu unsur tari yang mencakup gerak dengan menggunakan pola lantai baris-berbaris, unsur karawitan yang menggunakan gendhing kemanak, dan unsur kidung yang menggunakan sekar kawi.

Bentuk tari bedhaya tidak lepas dari keberadaan istana sebagai sumber penciptaannya. Memiliki nilai-nilai filosofis dengan aturan yang baku mempengaruhi bentuk koreografinya. Tari bedhaya di Kasunanan Surakarta memiliki sembilan penari yang masing-masing berperan sebagai endhel ajeg, batak, endhel weton, apit ngarep, apit mburi, gulu, apit meneng, dhadha, dan buncit. Pandangan masyarakat Jawa, angka sembilan merupakan jumlah bilangan terbesar yang berkaitan dengan simbol makrokosmos dan mikrokosmos yang meyakini bahwa terdapat kesejajaran antara alam semesta dengan manusia. Kesembilan penari bedhaya membentuk pola lantai yang terkait dengan konsep manunggaling kawula Gusti yaitu proses perjalanan hidup manusia dari lahir, hidup, dan mati yaitu pola lantai montor mabur, perangan, dan tigatiga. Selain itu, terdapat pola lantai jejer wayang, blumbangan, dan beberapa lainnya.

Sembilan penari bedhaya memperlihatkan adanya keseragaman dalam rias dan busananya yaitu model basahan. Model bahasan ini diwujudkan dengan pemakaian busana dodot ageng bangun tulak dan rias paesan. Riasan seperti ini biasanya digunakan sebagai rias pengantin wanita Jawa. Jika dikaitkan dengan gambaran tari Bedhaya Ketawang (bedhaya tertua di istana), bahwa riasan ini menggambarkan pernikahan Kanjeng Ratu Kidul dengan Panembahan Senopati.

Sajian tari bedhaya diiringi dengan gamelan Jawa yang menggunakan kehadiran alat musik kemanak sebagai ciri khas. Iringan musik yang mendayu-dayu, tari bedhaya di istana ditarikan dengan halus, pelan, lemah lembut, dan kemantapan rasa penari dengan gendhing kemanak yang menyatu dengan tembang sehingga menghadirkan suasana yang regu, wingit, wibawa, dan magis yang seolah-olah berada di alam lain. Hal ini berkaitan dengan salah satu fungsi tari bedhaya sebagai sarana olah semedi yang harus dilakukan oleh raja. Raja harus melakukan olah semedi untuk sarana pengendalian diri karena pada saat itu bentuk ratu gung binathara3 sangat mutlak di mana raja adalah penentu kebijakan dalam 
memimpin rakyatnya. Untuk itu, raja harus melakukan ritual semedi untuk menjauhkan tindakan sewenang-wenangnya (Dewi, 1994:43).

Perkembangannya, bentuk tari bedhaya semakin beragam dengan gaya masing-masing. Terlebih setelah tari bedhaya diperbolehkan keluar istana (kecuali Bedhaya Ketawang) benyak susunan tari bedhaya baru yang berpijak pada tari bedhaya di istana. Di luar istana, banyak koreografer yang menyusun tari bedhaya dengan tafsir masingmasing. Secara bentuk koreografi, juga memiliki banyak keragaman seperti adanya penggunaan tujuh penari, penggunaan penari putra, penggunaan model rias dan busana yang bukan paes dodot ageng, penggarapan musik tari yang beragam, dan perlengkapan lainnya.

Seperti dalam kasus tari Bedhaya Sarpa Rodra ini, sebagai bentuk tari model garap bedhaya, Saryuni mencoba bereksperimen seluasluasnya untuk mewujudkan sajian tari bedhaya dengan corak yang berbeda dari bedhaya lainnya.

\section{Pembentukan Koreografi Bedhaya Sarpa Rodra}

Pembentukan koreografi Bedhaya Sarpa

Rodra meliputi tiga hal yaitu bentuk gerak, teknik gerak dan isi. Bentuk gerak dalam tari Bedhaya Sarpa Rodra dianalisis dengan melihat struktur pola gerakan tubuh yang sering disebut motif gerak. Motif gerak dipahami sebagai kesatuan tata hubungan unsur-unsur gerak tari atau elemen gerak dari tubuh penari yang memiliki tema atau motivasi tertentu (Hadi, 2011: 39). Motif gerak dalam tari Bedhaya Sarpa Rodra dianalisis menggunakan teori Effortshape dengan notasi Laban sebagai pencatatan geraknya. Effort merupakan sebuah proses atau usaha pembentukan gerak melalui proses ketubuhan, tema, dan dinamika. Shape merupakan bentuk yang dihasilkan dari lintasan gerak yang terdiri dari lengkung dan lurus, lintasan lantai atau pola lantai, level yang terdiri dari rendah, sedang, dan tinggi, serta volume gerak besar dan kecil (Hutchinson, 1981:11-12).

\section{Ketubuhan Penari}

Kemampuan ketubuhan penari dalam pembentukan motif gerak tari Bedhaya Sarpa Rodra dilihat dari jenis kelamin dan postur tubuh penari yang mempengaruhi terbentuknya motif-motif gerak dalam karya tari. Penari dalam tari Bedhaya Sarpa Rodra dapat dikatakan memiliki kemampuan ketubuhan yang baik. Secara fisik, penari memiliki ukuran tubuh dengan batas normal tinggi badan \pm 160 $\mathrm{cm}$ dan berat badan $\pm 56,5 \mathrm{~kg}$. Ukuran tubuh penari tersebut secara visual dapat melakukan gerakgerak dengan teknik gerak individu yang baik. Di antara tujuh penari memiliki kemampuan kepenarian yang sama rata meskipun memiliki postur tubuh yang berbeda. Ukuran tubuh penari dalam tari Bedhaya Sarpa Rodra ini dapat memudahkan penari dalam membentuk motif-motif gerak yang cenderung kasar, kuat, cepat, dan rowa (besar) seperti pada bentuk gerak tari Bedhaya Sarpa Rodra. Bentuk gerak tari Bedhaya Sarpa Rodra tersebut akan terwujud dengan pergerakan penari yang dipengaruhi oleh waktu gerak, kelincahan gerak, tenaga, dan lintasan geraknya sehingga ketika melihat batas ukuran normal tubuh penari dalam tari Bedhaya Sarpa Rodra cukup mewakili bentuk geraknya.

\section{Tema}

Pembentukan motif gerak dalam tari Bedhaya Sarpa Rodra tidak lepas dari tema tari. Tema global warming yang menekankan pada keserakahan manusia digambarkan oleh tokoh Sarpakenaka sehingga tari Bedhaya Sarpa Rodra menghasilkan motif gerak yang cenderung menggambarkan gerak ular seperti meliuk-liuk dan bergetar. Motif gerak tersebut dihasilkan dengan bentuk gerak yang cenderung menggambarkan wujud ular. Motif gerak liukan diwujudkan dengan menggerakkan badan membentuk lintasan garis gelombang atau seperti huruf "S". Misalnya dengan gerak yang bermula dari posisi tumpuan kaki dan lutut ditekuk menuju posisi tumpuan kaki berbentuk "jinjit" dengan gerak badan didorong ke kiri kemudian ke kanan kembali ke kiri dan seterusnya hingga posisi telapak kaki jinjit. Sebagai wujud ular, terdapat bentuk tangan yang menyerupai kepala ular dengan mulut terbuka.

\section{Dinamika}

Dinamika dalam tari dipahami sebagai segala perubahan gerak dengan adanya variasivariasi penggunaan elemen gerak yaitu ruang, tenaga, dan waktu. Melihat dari sisi keruangan, perubahan gerak Bedhaya Sarpa Rodra menghasilkan empat pola keruangan yaitu menyebar secara acak, menyebar secara beraturan, menggerombol secara acak, dan menggerombol secara beraturan. Hal ini juga dipengaruhi oleh aspek garis, volume, arah, level, dan fokus. 


\section{GEARR hamisanibuson}

Melihat dinamika tenaga penari, maka berkaitan dengan kesiapan gerak penari dan waktu gerak. Dinamika tari dalam aspek tenaga berkaitan dengan kesiapan penari dalam bergerak. Tenaga dipahami sebagai kekuatan penari dalam menghasilkan gerak. Dapat dipahami seperti halus dan tajam. Hal ini terletak pada kontrol fisik penari yaitu pengaturan gerak dengan intensitas dan tekanan atau hentakan-hentakan tertentu. Gerak yang didasari oleh kekuatan fisik penari dapat menghasilkan kualitas gerak seperti pelanlembut bertenaga, cepat-lembut tanpa banyak tenaga, cepat-tajam bertenaga, pelan-halus tanpa tenaga, tajam dengan sedikit tenaga dan beberapa lainnya serta dipertegas melalui aksen atau tekanan gerak yang dapat menarik perhatian penonton. Melalui proses tersebut dapat dilihat munculnya emosi jiwa gerak penari dengan berbagai macam ekspresi.

\section{Lintasan Gerak}

Lintasan gerak merupakan Shape atau bentuk yang dihasilkan atas Effort. Lintasan gerak dapat berupa bentuk garis lengkung (gelombang, spiral), dan lurus. Lintasan garis lengkung biasanya memberikan kesan kelembutan, halus, dan gemulai. Lintasan gerak lengkung ini diwujudkan dalam motif gerak sindhet, hoyogan, kayang, putaran, seblakan dan liukan. Motif gerak tersebut menekankan pada gerak tubuh yang membentuk lintasan garis lengkung sehingga tubuh dapat digerakkan secara lentur atau tidak kaku. Lintasan garis lurus diwujudkan dalam gerak tubuh yang terkesan kaku, tajam, tegang dan keras seperti garis vertikal, horizontal, miring, zigzag, dan patahpatah.

\section{Lintasan Pola Lantai}

Lintasan lantai atau pola lantai atau design lantai dipahami sebagai pola yang dilintasi oleh gerak di atas lantai dari ruang pentas. Seperti pada lintasan gerak penari, bentuk lintasan lantai juga dihasilkan dari lintasan gerak penari yang berupa garis lurus dan lengkung. Lintasan garis lurus akan menghasilkan pola lantai menyerupai kerucut, segitiga, segiempat, segilima, dan beberapa segi lainnya sedangkan lintasan garis lengkung dapat membentuk pola lantai lingkaran, setengah lingkaran, atau zigzag lengkung seperti ular dan sebagainnya.

Pola lantai yang terbentuk dalam tari Bedhaya Sarpa Rodra cenderung terbentuk dari lintasan gerak garis lurus seperti pola segitiga, segiempat, zigzag, dan lainnya. Sedangkan pola dengan lintasan garis lengkung terlihat pada bagian beksan dengan satu penari bergerak dan keenam penari lainnya dengan level bawah.

Lintasan pola lantai terbentuk dari motif gerak yang cenderung menggunakan gerak kaki seperti gerak srisig yang terbentuk dengan melangkahkan kaki ke depan atau ke belakang dengan tumit diangkat ke atas (jinjit) dan jarak antara tumpuan kaki kurang lebih satu kaki secara cepat.

\section{Level}

Level dalam koreografi dibedakan menjadi tiga bagian yaitu level rendah, level sedang, dan level tinggi. Level rendah biasanya ditandai dengan posisi tubuh merendah atau berat ke bawah seperti duduk, jengkeng, sila, ndodok, merangkak, tidur, berguling dan sebagainya. Level rendah dalam tari Bedhaya Sarpa Rodra diwujudkan pada motif gerak jengkeng dan sila. Level sedang atau medium merupakan posisi normal tubuh penari di antara level rendah dan level tinggi. Level sedang biasanya juga ditandai oleh posisi tangan yang horisontal dan tubuh tegak yang disangga oleh kedua kaki. Beberapa di antaranya adalah motif gerak kapangkapang, lumaksana, kenseran, sekar suwun, pendhapan, getaran, meliuk. Level tinggi dapat ditandai dengan posisi tubuh dan tangan diangkat ke atas serta posisi kaki menapak dengan tumpuan telapak kaki depan dalam istilah Jawa adalah jinjit.

\section{Volume Gerak}

Volume dalam gerak tari dapat dipahami sebagai ukuran atau jangkauan gerak yang dihasilkan dari besar atau kecilnya ruang yang digunakan penari. Besar kecilnya jangkauan gerak tari pada umumnya disesuaikan dengan isi atau tema tari dan suasana adegan. Seperti penggambaran raksasa dalam suasana marah cenderung menggunakan jangkauan gerak yang besar, penggambaran putri Jawa yang sedang sedih cenderung menggunakan jangkauan gerak yang kecil.

Tari Bedhaya Sarpa Rodra cenderung menggunakan gerak yang bervolume besar meskipun ada bagian-bagian dengan volume kecil. Hal ini disesuaikan oleh tema dan tokoh dalam tari yaitu keserakahan dan sosok Sarpakenaka yang merupakan seorang raksasa. Keserakahan 
diidentikkan dengan hal-hal yang berlebihan sedangkan raksasa diidentikkan sebagai sosok yang besar. Maka gerak-gerak yang tersusun menggunakan volume besar.

Berpijak pada tari putri gaya Surakarta, Saryuni menyusun beberapa gerak dengan cara memperbesar volume geraknya. Seperti pada gerak sindhet, hoyogan, penthangan tangan, leyekan tubuh, lintasan gerak tangan, pose tangan dengan mengangkat lengan atasnya, pose kayang dengan mendorong tubuhnya ke belakang yang diikuti kedua tangan ditarik ke belakang. Secara keseluruhan jangkauan gerak dengan volume besar ditunjukkan dengan pola gerak badan, lintasan atau pose tangan, dan tolehan kepala dengan jarak pandang mata yang jauh.

Motif gerak Bedhaya Sarpa Rodra juga disusun dengan adanya variasi gerak, pengulangan gerak, perpindahan gerak dan adanya kesatuan gerak. Hal ini dilakukan untuk menghindari adanya kemonotonan sajian. Secara teknik, motif gerak Bedhaya Sarpa Rodra tidak hanya menggunakan motif gerak tari bedhaya yang sudah ada, tetapi lebih menonjolkan karakter Sarpakenaka.

Teknik gerak Bedhaya Sarpa Rodra dilihat menggunakan Hastasawanda mulai dari Pacak, sikap adeg penari lebih menampilkan kesan angkuh dengan adanya membusungkan dada, mengangkat dagu, memperbesar volume gerak. Pancat, pijakan awal dan peralihan gerak dengan menghadirkan tekanan tertentu (pengolahan tempo cepat dan lambat). Ulat, pandangan mata penari lebih terkesan galak, seksi, dan menggoda. Lulut, ditunjukkan dengan adanya kesatuan gerak dengan penari yang sudah tidak dipikirkan lagi. Penari bergerak sesuai dengan irama rasa gerak penari. Luwes, keluwesan penari ditunjukkan dengan adanya peralihan karakter dari yang lembut menjadi tegas sehingga tidak terlihat kaku. Wiled penari ditunjukkan dengan kemampuan individual penari, dimana ada saatnya mereka menyamakan wiled saat gerak kelompok dan ada saatnya mereka menunjukkan wiled bawaan individu saat gerak tunggal. Secara irama dan gendhing, penari melakukan gerak yang sesuai dengan irama musiknya sesuai dengan pathokan gendhing dan beberapa bagian juga ditunjukkan dengan adanya pengontrasan irama.

\section{ASPEK KOREOGRAFI BEDHAYA SARPA RODRA}

\section{Deskripsi Tari}

Tari Bedhaya Sarpa Rodra merupakan tarian model bedhaya di luar istana yang ditarikan oleh tujuh penari putri. Kata Sarpa diambil dari nama tokoh dalam pewayangan Sarpakenaka yang berarti ular dan Rodra berarti besar atau pancaran kekuatan dahsyat yang menggetarkan. Tari Bedhaya Sarpa Rodra ini dilatarbelakangi oleh adanya isu global warming yang sedang marak menjadi bahan perbincangan di berbagai kalangan. Kerusakan alam yang disebabkan oleh keserakahan manusia menyebabkan adanya ketidakseimbangan struktur kehidupan.

Tari Bedhaya Sarpa Rodra menggambarkan tokoh Sarpakenaka dengan segala sifat, tingkah, ego, dan keserakahannya. Sarpakenaka digambarkan sebagai sosok raksasa wanita yang memiliki nafsu birahi yang tinggi. Kehidupannya penuh dengan kontroversi yang berhubungan dengan laki-laki. Tidak pernah puas hanya dengan satu laki-laki saja, memiliki banyak selingkuhan, sensual, hiperseks, dan selalu terobsesi menakhlukan kaum laki-laki agar bertekuk lutut padanya.

\section{Judul Tari}

Sesuai dengan temanya, karya tari susunan Saryuni Padminingsih ini diberi judul "Sarpa Rodra" atau biasanya disebut "Bedhaya Sarpa Rodra". Judul Sarpa Rodra diambil dari pengertian kata Sarpa yang berarti ular dan Rodra dapat diartikan besar atau pancaran kekuatan dahsyat menggetarkan. Kata Sarpa sendiri diambil dari nama Sarpakenaka, yaitu tokoh raksasa wanita dalam pewayangan yang menurut Saryuni sesuai dengan penggambaran sifat-sifat manusia.

\section{Tema tari}

Tema tari Bedhaya Sarpa Rodra bersumber dari pengalaman dan situasi kehidupan sehari-hari yaitu mengenai kondisi dan situasi kehidupan manusia. Tema global warming yang begitu luas dipersempit menjadi substansi permasalahan ulah, sifat, ego, dan keserakahan manusia.

\section{Penari}

Menurut Y. Sumandiyo Hadi terdapat tiga aspek dalam mempertimbangkan penari yaitu bedasarkan jenis kelamin penari, jumlah penari, dan 


\section{GE[AR Juman Sscib butusa}

postur penari (Hadi, 2003:2-22). Ketiga aspek tersebut berkaitan dengan konsep dasar sebuah karya tari seperti tema tari atau latar belakang cerita garapannya.

Bedhaya Sarpa Rodra menggunakan jumlah tujuh penari putri sebagai simbolis jumlah tari penari bedhaya. Jumlah tujuh penari ini biasanya digunakan sebagai penari bedhaya di Mangkunegaran. Jumlah tujuh penari ini juga disesuaikan dengan kondisi ruang pentas yang pada saat itu lebih tepat jika diisi oleh tujuh penari yaitu di Teater Kecil ISI Surakarta. Selain itu, Saryuni sengaja tidak memilih penari berdasarkan kemiripan dari segi fisik yang umumnya diterapkan pada tari bedhaya tradisi lainnya namun kemampuan penari yang menjadi aspek utamanya. Melihat pandangan Gendhon Humardani bahwa yang terpenting dari pemilihan seorang penari adalah kemampuan kepenariannya, Saryuni menerapkannya dalam pemilihan penari pada tari Bedhaya Sarpa Rodra.

Tari bedhaya yang umumnya ditarikan dengan penari yang memiliki kesamaan postur tubuh, tari Bedhaya Sarpa Rodra justru menerapkan penari dengan postur tubuh yang bervariasi. Terdapat tiga penari yang berpostur pendek dan empat penari berpostur tinggi. Ada penari yang bertubuh pendek gemuk, ada juga yang tinggi dan kurus. Perbedaan inilah yang diharapkan dapat memperkaya ragam gerak dalam tari Bedhaya Sarpa Rodra ini dengan memunculkan image, interpretasi, mimik, dan karakter yang alami meskipun berpijak pada konsep garapan yang sama yaitu Sarpakenaka.

\section{Gerak tari}

Gerak tari Bedhaya Sarpa Rodra ini tersusun berdasarkan konsep Sarpakenaka sebagai raksasa berwujud ular yang memiliki kuku panjang. Berdasarkan konsep ini, Saryuni menyusun atau menciptakan motif-motif gerak yang cenderung menggambarkan sosok Sarpakenaka tersebut. Gerak dasar yang digunakan dengan pola gerak bervolume besar yaitu dengan membuka atau menonjolkan dada dengan kedua lengan diangkat ke atas. Begitu juga dengan pola jari-jari tangan yang direnggangkan seakan mencakar. Selain itu, gerakgerak yang menekankan liukan tubuh juga digunakan sebagai ciri khas garapan gerak tarinya.

Meskipun demikian, tidak meninggalkan pijakan vokabuler gerak tradisi tari putri seperti lumaksana, kembang pepe, sekar suwun, dan pendhapan. Dalam hal ini, Saryuni menekankan pada gerak yang merubah ukuran volume gerak penari.
Sebagai contoh, kembang pepe yang hanya dilakukan dengan memutar badan dengan mayuk yang tidak mencapai $90^{\circ}$, justru gerak tersebut dalam tari Bedhaya Sarpa Rodra ini dibuat mencapai $\pm 90^{\circ}$ dan dengan lintasan gerak garis lengkungan sehingga jika ditafsirkan seperti gerak ular yang sedang melata. Ini menjadi salah satu bentuk pengembangan gerak yang berpijak pada vokabuler gerak tradisi putri gaya Surakarta.

Menurut Desmon Morris, motif gerak dalam tari Bedhaya Sarpa Rodra dapat dibagi menjadi empat, yaitu gerak maknawi, gerak murni, gerak baton signal, gerak berpindah tempat. Dapat dituliskan ke dalam notasi Laban sebagai pencataan tarinya.

Adapun beberapa contoh motif geraknya yang telah dikategorikan sebagai berikut.
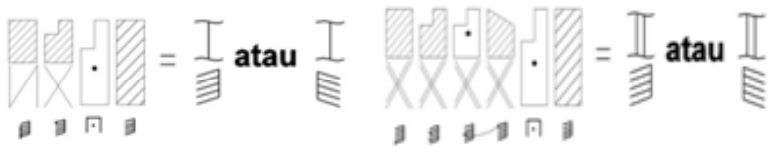

\section{Kunci Tangan I (nogo rangsang), Kunci Tangan II (ngithing)}

1. Gerak Maknawi atau gesture. Gerak maknawi yang dimaksud adalah gerak yang secara imitatif dan interpretatf dilakukan untuk mewujudkan simbol-simbol maknawi. Tari Bedhaya Sarpa Rodra sebagai karya tari yang terinspirasi pada sosok Sarpakenaka sebagai ular, maka dalam perwujudan geraknya didominasi oleh gerak-gerak yang meniru gerak ular, seperti motif gerak liukan berikut.

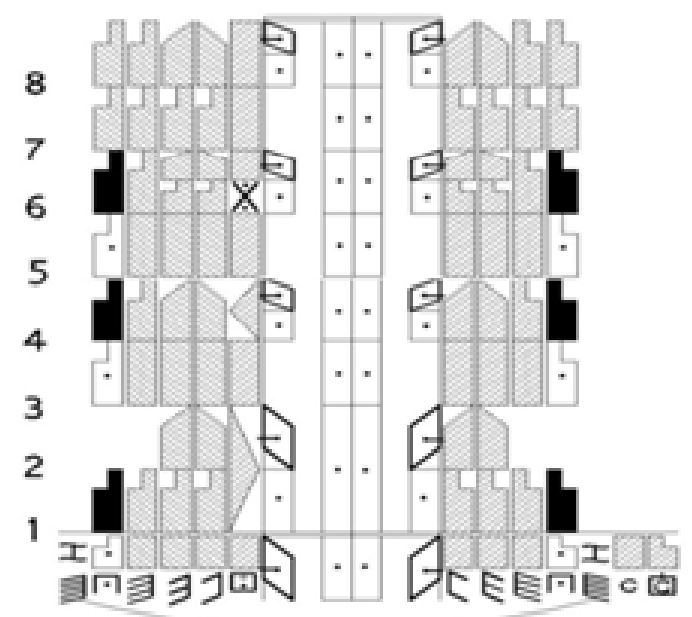

Notasi 1. Gerak Maknawi, motif gerak liukan. 
2. Gerak Murni. Gerak murni lebih mengutamakan estetik dan tidak menyampaikan pesan maknawi. Dalam hal ini, motif gerak kembang pepe merupakan salah satu motif gerak yang dapat dikategorikan ke dalam gerak murni.

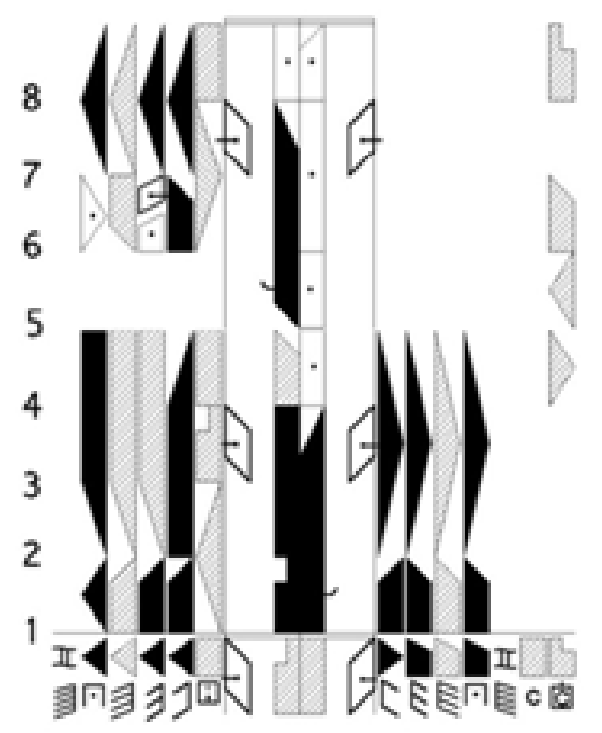

Notasi 2. Gerak Murni, motif gerak kembang pepe.

3. Gerak Baton Signal. Gerak baton signal merupakan gerak yang dilakukan sebagai perwujudan penguat ekspresi. Gerak ini diwujudkan dalam motif gerak liukan dengan merentangkan kedua tangan.

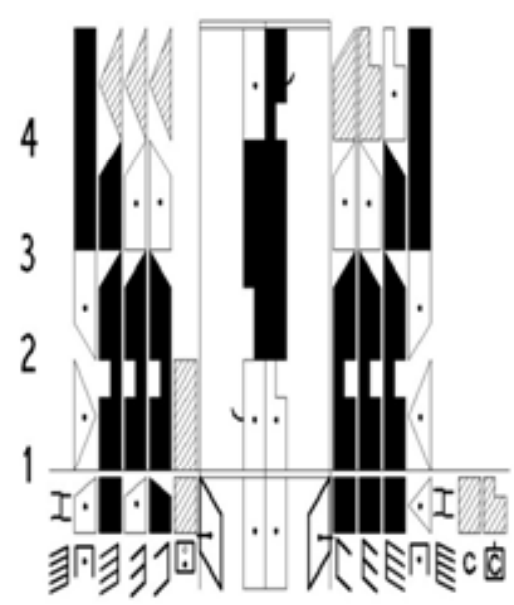

Notasi 3. Gerak Baton Signal, motif gerak nyathok.

3. Gerak berpindah tempat atau locomotion. Gerak berpindah tempat diwujudkan ke dalam beberapa motif gerak seperti srisig, kenser, tranjal, lompat, dan sebagainya.Dalam hal ini, srisig menjadi dominan dalam gerak perpindahan tempat. Adapun salah satu motif gerak srisig sebagai berikut.

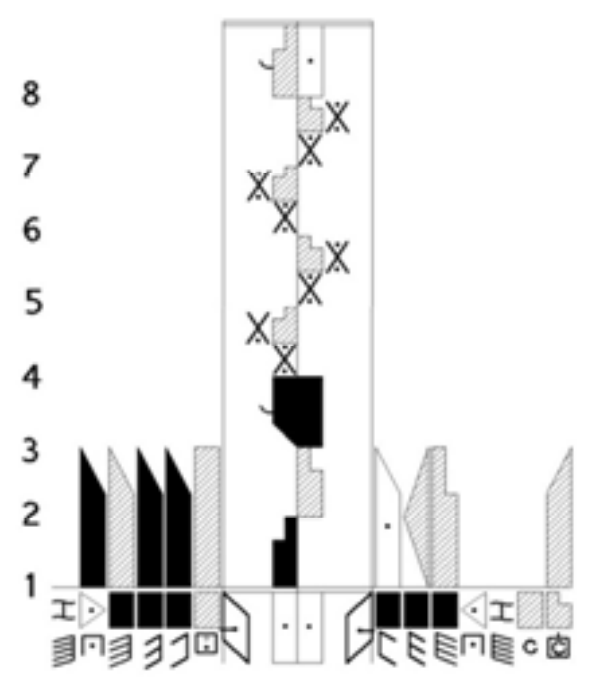

Notasi 4. Gerak berpindah tempat atau locomotion, motif gerak srisig.

\section{Musik Tari}

Musik tari Bedhaya Sarpa Rodra merupakan garap musik tari bedhaya yang menghadirkan keunikan tersendiri dalam penggarapananya. Secara konsep, musik tari Bedhaya Sarpa Rodra berangkat dari makna "kala" yang mengandung dua pengertian yaitu waktu atau zaman dan raksasa. Berangkat dari makna "kala" yang dipahami sebagai waktu atau zaman, musiknya berbicara mengenai makna filosofis waktu yang merupakan elemen penting dalam kehidupan. Sedangkan makna "kala" juga dipahami sebagai raksasa yang disimbolkan oleh sosok Sarpakenaka.

Materi musiknya dieksplorasi dan dikembangkan dengan mengkawinkan materi musik karawitan tradisi dan materi musik baru yang didapat pada saat proses berlangsung. Dalam hal ini musik disusun dengan memadukan antara nada "pentatonik" dan "diatonik". Artinya, dalam penggarapanya penyusun musik mencoba memperluas jangkauan wilayah nada yang terdapat pada laras pelog sehingga seakan-akan terdengar nada diatonis. Dalam penggarapan vokalnya dengan memaksimalkan jangkauan wilayah nada slendro dan pelog. Seperti nada tinggi yang biasanya digunakan dengan nada 3 (mi) dicoba sampai nada 6 (la) dan nada rendah 3 (mi) dicoba sampai nada 1 (do) (Wahyudi Sutrisno, wawancara 5 November 2015). 


\section{GEELR Jumal sori buatsa}

Penggarapan musik tersebut tersusun dengan alat musik gamelan Jawa yang dipadukan dengan gamelan Bali dan beberapa alat musik seperti biola, jimbe, bedug, terbang, dan kenthongan. Menurut Wahyudi Sutrisno, gamelan Bali memiliki warna bunyi yang "melengking" sehingga memberikan nuansa yang berbeda jika dipadukan dengan gamelan Jawa yang lebih soft. Selain itu, gamelan Bali memiliki karakter nada "ngumbang ngisep" yaitu dengan nada senama tetapi memiliki frekuensi yang sedikit berbeda. Gamelan Bali yang digunakan telah mengalami modifikasi yaitu dengan menambahkan nada 4 (pat) dan 1 (ji) yang pada saat itu jarang digunakan dalam gamelan Bali. Selain gamelan Bali, alat musik biola sengaja digunakan untuk mempertegas warna bunyi yang dihasilkan dan lebih fleksibel dalam mewadahi garapangarapan vokalnya. Sedangkan perkusi (jimbe, bedug, terbang, dan kenthongan) dapat memberikan aksen dinamis ada bagian-bagian tertentu.

Perpaduan alat-alat musik tersebut memunculkan adanya nada-nada baru yang menurut Wahyudi Sutrisno cocok dilagukan dengan syair bahasa Jawa dan bahasa Indonesia. Maka dari itu, inilah yang menjadi pertimbangan untuk penggunaan syair bahasa Jawa dan bahasa Indonesia.

Penggarapan musik tari Bedhaya Sarpa Rodra masih berpijak pada pola kemanakan yang ada dalam tari bedhaya tradisi. Hal ini diwujudkan pada bagian beksan dengan adegan "love dance" yaitu dua penari sebagai sosok Sarpakenaka dan lima penari lainnya menjadi pendukung suasana. Bagian ini biasanya terdapat dalam bagian beksan perangan dalam tari bedhaya tradisi. Pola kemanakan digarap dengan paduan bunyi lainnya seperti garap "mbali" dan vokal. Seperti dalam tari bedhaya tradisi, musik tari Bedhaya Sarpa Rodra juga menekankan garap vokalnya dengan berpijak pada konsep "kala" sebagai waktu dan raksasa yang diwujudkan dalam syair-syair lagunya.

\section{Rias dan busana}

Secara umum, rias dan busana tari Bedhaya Sarpa Rodra menggunakan konsep rias busana paes dan dodot seperti tari bedhaya yang ada di istana. Rias wajah tari Bedhaya Sarpa Rodra menggunakan rias mata sipatan4 yang terbentuk oleh warna eyeshadow5 hijau dan merah. Alis dibentuk menjangan ranggah berwarna hitam yang searah dan sejajar dengan garis eyeshadow. Bentuk seperti itu memberikan kesan galak, sereng, dan tajam pada karakter tokoh Sarpakenaka. Hal ini menegaskan pada karakter Sarpakenaka yang ganas. Rias wajah bagian kening menggunakan paes yang berbentuk segitiga dengan warna hijau dan garis tepi berwarna emas. Pada pertengahan pangkal alis terdapat laler mencok segi empat hijau kecil. Penggunaan rias paes semacam itu memperkuat penggambaran wujud ular dari sosok Sarpakenaka.

Rias wajah dalam tari Bedhaya Sarpa Rodra ini sedikit berbeda dengan rias wajah dalam tari bedhaya tradisi yang menggunakan paes Solo seperti dalam tari Bedhaya Ketawang atau rias cantik tanpa paes seperti tari Bedhaya Ela-ela yang menggunakan kadal menek. Rias wajah dalam tari Bedhaya Sarpa Rodra ini menonjolkan karakter tokoh Sarpakenaka sehingga menekankan ketebalan warna kelopak mata dan garis alis agar terlihat tajam dan jelas. Pemilihan warna eyeshadow hijau tua dan dibaurkan dengan merah juga dapat memperkuat kesan karakter tokoh.

Tatanan rambut dalam tari Bedhaya Sarpa Rodramenggunakan modifikasi dari gelung gedhe yang dipadukan dengan rajangan daun pandan yang telah dirajut. Rajangan daun pandan diletakan di bawah gelung membentuk setengah lingkaran mengikuti bentuk tepi gelung dan di atas daun pandan diletakkan rangkaian bunga melati (keket) menyesuaikan bentuk daun pandan. Di atas bunga melati tepatnya di bagian tengah diletakan tiga bunga aster yang membentuk segitiga.

Busananya dodot ageng menggunakan warna hijau dengan motif alas-alasan, kain santung putih yang digunakan untuk samparan, dan sampur yang berwarna dasar putih dengan corak hijau yang senada dengan warna dodot. Selain itu, dilengkapi dengan sabuk berwarna emas beserta thothoknya dan buntal yaitu rangkaian daun kroton, bunga kenikir, dan daun beringin yang dilingkarkan pada pinggul penari.

Penggunaan rias dan busana tari Bedhaya Sarpa Rodra dilengkapi dengan aksesoris perhiasan seperti kalung yang dipakai melingkari leher, klat bahu yang melingkar di lengan atas, gelang di pergelangan tangan, dan giwang di telinga, sumping kudup di telinga, centhung di kepala bagian depan, sirkam pada sanggul bagian atas, cundhuk mentul di bagian kanan dan kiri sanggul atas, dan grodha di bagian sanggul atas belakang. Pemilihan perhiasan dipilih dengan warna emas dengan butiran permata yang menimbulkan kesan cantik dan glamor. Meskipun seorang raksasa wanita, Sarpakenaka tetap merupakan putri kerajaan 
sehingga diwujudkan dengan balutan rias dan busana yang mewah.

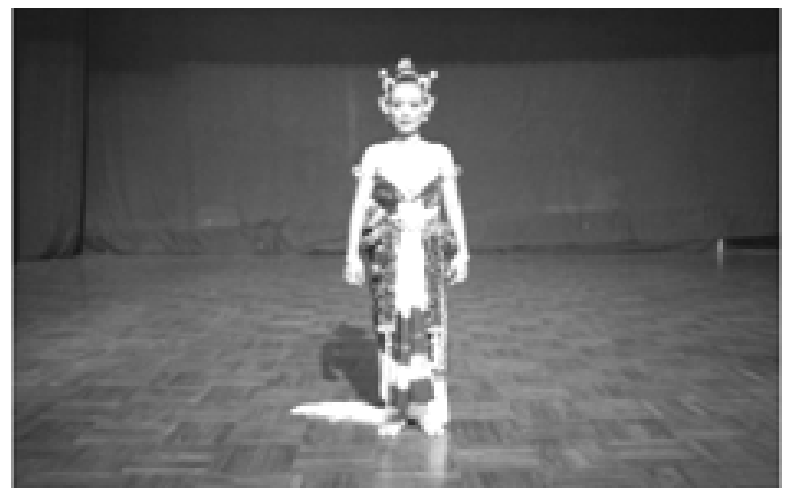

Gambar 1. Rias busana model paes dan dodot. (foto Ryndhu, 2015)

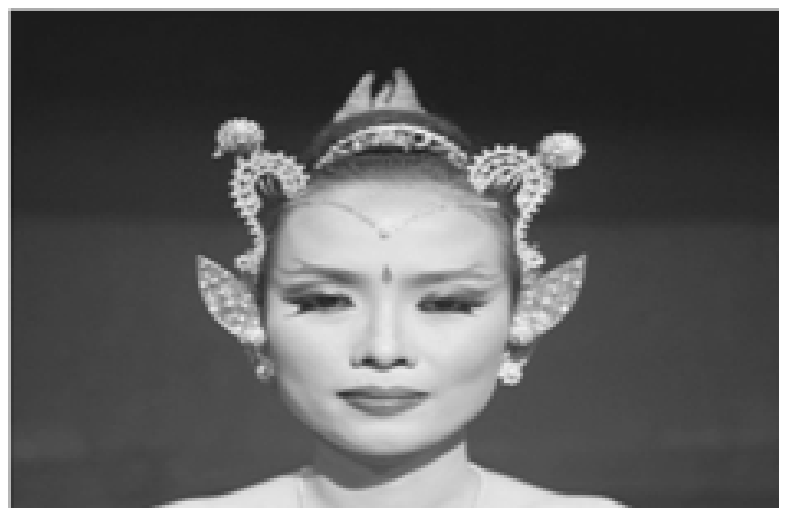

Gambar 2. Rias wajah model paesan. (foto Ryndhu, 2015)

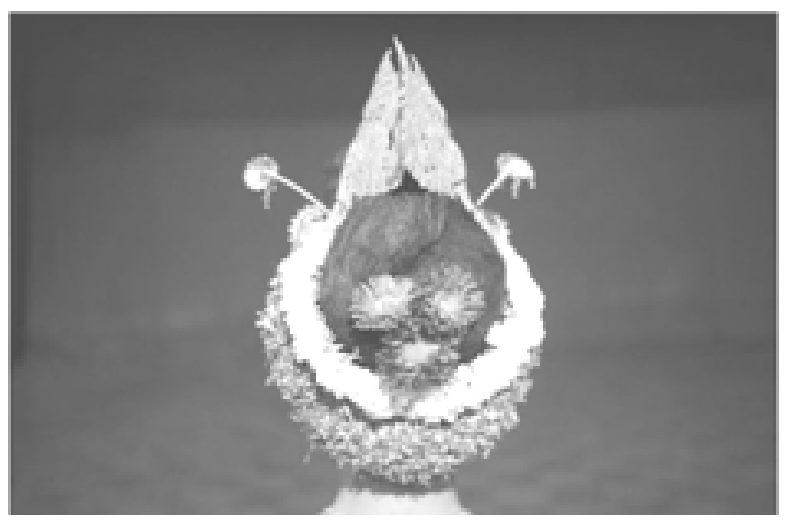

Gambar 3. Tatanan rambut dengan rajangan daun pandan. (foto Ryndhu, 2015)

\section{Pola lantai}

Pola lantai merupakan wujud garis yang terbentuk oleh lintasan gerak para penari di atas lantai ruang pentas. Dapat dipahami juga sebagai garis yang terbentuk oleh formasi atau komposisi penari. Pola lantai dipengaruhi oleh aspek arah penari dalam bergerak. Aspek arah tersebut berhubungan dengan langkah dari suatu gerakan penari, dapat berupa garis lurus atau garis lengkung.

Pola lantai dalam tari Bedhaya Sarpa Rodra memiliki variasi bentuk pola yang beragam. Terdapat beberapa menggunakan pola lantai tari bedhaya yang telah ada sebelumnya seperti montor mabur, urut kacang dan beberapa lainnya merupakan susunan baru.

Beberapa contoh pola lantai yang dalam tari Bedhaya Sarpa Rodra sebagai berikut.

\section{Keterangan:}

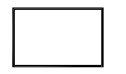

panggung berbentuk persegi panjang, menghadap ke arah pembaca,

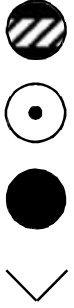

: menunjukkan level tinggi,

: menunjukkan level sedang,

: menunjukkan level rendah,

: menunjukkan arah hadap penari.

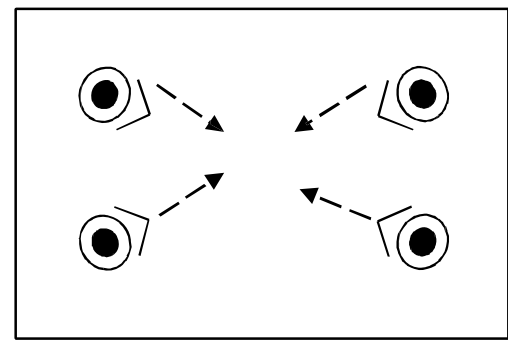

Gambar 4. Lintasan gerak kapang-kapang.

Pola lantai di atas menunjukkan awal sajian tari dengan empat penari yang muncul dari empat sudut panggung. Pola lantai ini disusun dengan pijakan keblat papat lima pancer di mana penari muncul dari empat arah.

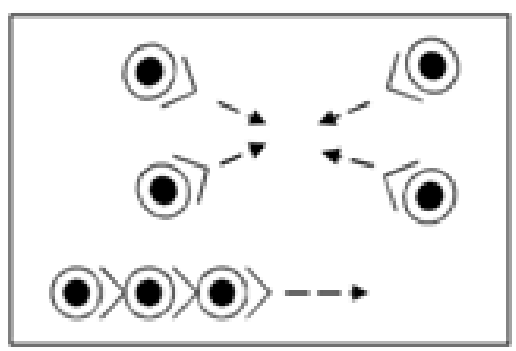

Gambar 5. Lintasan gerak kapang-kapang. 


\section{GELAR Jumal sori buatsag}

Tiga penari menyusul berbaris lurus dari arah kanan depan panggung. Pola lantai di awal sajian ini digunakan sebagai pola lantai dengan motif gerak kapang-kapang. Jika dilihat pada tari- tari bedhaya sebelumnya atau yang masih terikat oleh kaidah istana biasanya menggunakan bentuk pola lantai urut kacang atau baris berbaris satu arah untuk menuju ke pola lantai sembahan.

Penari membentuk lintasan pola lantai dengan garis lurus dari gawang belakang menuju tengah dengan lumaksana nayung dan kenseran.

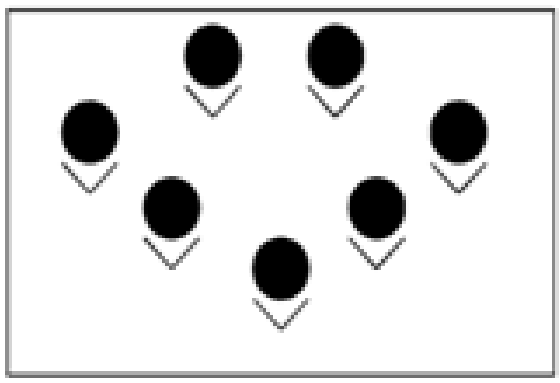

Gambar 6. Pola lantai Mata Panah yang digunakan dalam motif sembahan yang dilakukan dengan level bawah penari yaitu jengkeng.

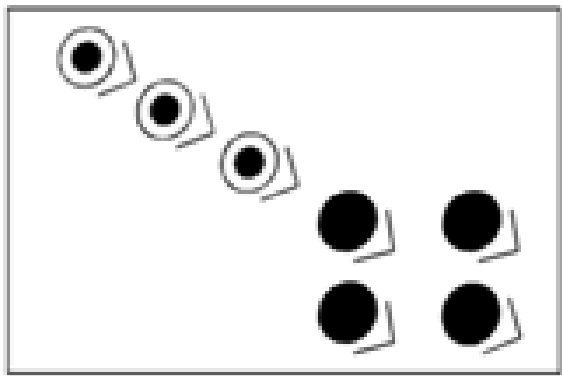

Gambar 7. Pola lantai montor mabur.

Pola lantai montor mabur ini salah satu pola lantai yang biasanya digunakan dalam pola lantai bedhaya tradisi. Dalam hal ini, arah hadap penari ke pojok kiri panggung dengan empat penari jengkeng dan tiga penari berdiri.

Tari Bedhaya Sarpa Rodra memiliki beberapa susunan pola lantai yang sama yaitu pola lantai telu papat. Namun perbedaannya terdapat pada arah hadap, level penari, dan posisi penari. Adapun contoh susunan pola lantainya seperti berikut.

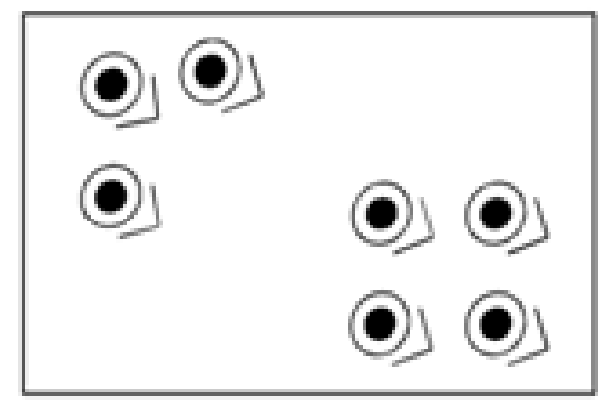

Gambar 8. Pola lantai telu papat.

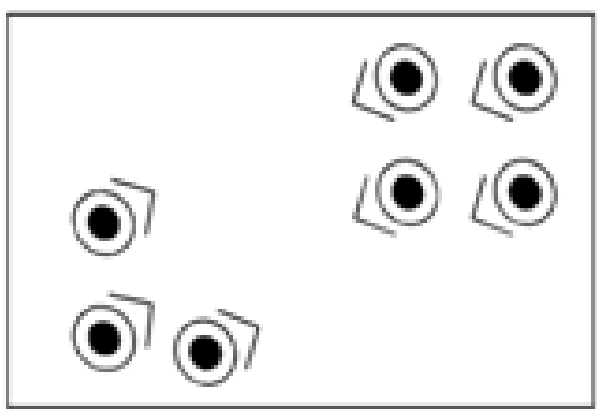

Gambar 9. Pola lantai telu papat.

Contoh pola lantai di atas terinspirasi dari pola lantai empat lima yang digunakan dalam tari bedhaya tradisi. Jumlah penari yang hanya tujuh orang, maka Saryuni mengemasnya menjadi pola lantai tiga empat.

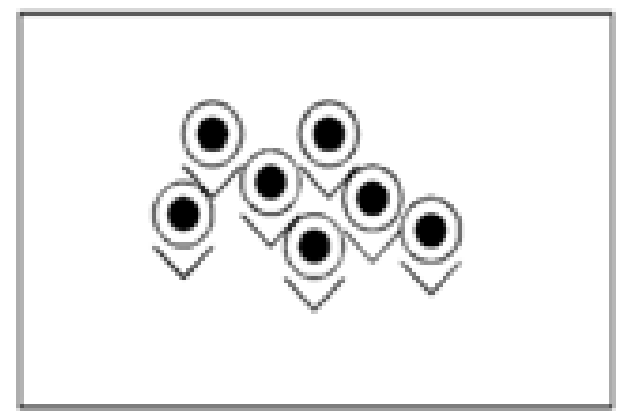

Gambar 10. Pola lantai ngempel.

Selain itu, terdapat pola lantai menggerombol secara acak juga digunakan dalam motif gerak yang sama yaitu gerak-gerak yang cenderung mengutamakan liukan dan getaran.

Pola lantai tari Bedhaya Sarpa Rodra juga meniru pola lantai yang digunakan dalam bagian perangan pada tari bedhaya tradisi dengan susunan 
yang berbeda. Adegan atau motif gerak yang dihadirkan bukan sebuah peperangan tetapi "love dance" yaitu gerak-gerak yang menonjolkan nafsu birahi Sarpakenaka. Bagian ini terdapat dua penari sebagai fokus dan penari lainnya sebagai pendukung adegan.

Begitu juga dengan pola lantai jejer wayang yang terdapat dalam tari bedhaya tradisi dihadirkan dalam pola lantai tari Bedhaya Sarpa Rodra.

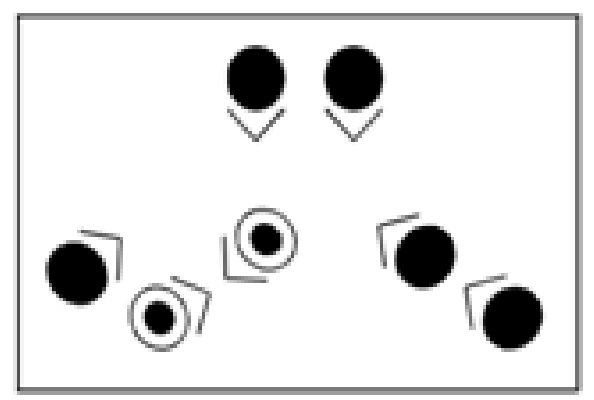

Gambar 11. Pola lantai perangan.

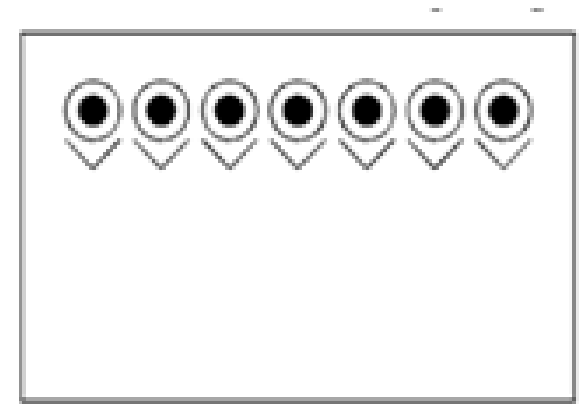

Gambar 12. Pola lantai jejer wayang.

\section{Ruang Pentas}

Tari Bedhaya Sarpa Rodra menggunakan ruang pentas berbentuk stage proscenium yaitu bentuk ruang pentas yang penontonnya dari satu arah saja. Tari Bedhaya Sarpa Rodra ditarikan di Teater Kecil ISI Surakarta. Ukuran ruang sekitar $10 \times$ 6 meter dan tidak menggunakan perlengkapan panggung seperti level lainnya. Ruang pentas tari Bedhaya Sarpa Rodra tidak menggunakan pendapa sebagaimana yang digunakan dalam pementasan tari bedhaya di istana. Untuk itu, pemanfaatan ruang dalam bergerak lebih leluasa karena tidak terbatasi oleh tiang atau "soko".

\section{Tata cahaya atau lighting}

Tari Bedhaya Sarpa Rodra menerapkan beberapa permainan cahaya dalam setiap suasana setiap adegannya. Pada awal sajian, tampak panggung terlihat gelap kemudian perlahan-lahan lampu mulai terang dengan warna putih dari tengah panggung hingga meluas ke sebagian besar panggung. Bagian ini untuk mengawali dimulainya sajian tari Bedhaya Sarpa Rodra yang diwujudkan dalam motif gerak kapang-kapang. Pada bagian ini lighting digunakan sebaga wujud pengenalan tokoh atau suasana yang sedang terjadi pada tokoh Sarpakenaka (Supriadi, wawancara 16 Oktober 2015).

Bagian pertengahan cahaya sedikit diredupkan atau dikurangi tingkat terangnya. Menuju pose-pose di gawang belakang cahaya berubah menjadi warna merah yang disertakan sorotan cahaya warna putih dari samping kanan dan kiri panggung belakang. Pada bagian ini, secara keseluruhan nuansa warna merah dan fokus pada barisan penari di panggung belakang dengan sorotan cahaya warna putih.

Menuju bagian sembahan akhir, cahaya diterangkan kembali dengan warna putih dan mengiringi motif gerak kapang-kapang penari yang menandakan telah selesainya pertunjukan, cahaya perlahan-lahan mulai diredupkan menjadi gelap.

\section{Perlengkapan atau property}

Tari Bedhaya Sarpa Rodra tidak menggunakan property dalam bentuk senjata atau setting panggungnya. Dalam penyajiannya, tari Bedhaya Sarpa Rodra menggunakan bunga sawur yang berupa mawar ditaburkan di atas panggung. Menurut Saryuni, penggunaan bunga sawur agar suasana ngengrengnya tercapai (Saryuni, wawancara 7 Oktober 2015).

\section{Kesimpulan}

Bentuk sajian tari Bedhaya Sarpa Rodra ini sebagai karya tari model bedhaya tidak terlepas dari pijakan dasar bentuk tari bedhaya tradisi seperti penari, rias dan busana, pola lantai, gerak tari, dan musik tari. Adanya aspek koreografi yang diterapkan di dalamnya merupakan bentuk dari hasil kesatuan atau keterkaitan aspek koreografi yang mengarah pada genre tari bedhaya seperti penggunaan jumlah tujuh penari dengan jenis kelamin perempuan, unsur rias dan busana tari bedhaya tradisi yang menggunakan model paes dan dodot meskipun telah mengalami modifikasi pada bagian-bagian tertentu, penyusunan pola lantai juga mengambil beberapa pola lantai dalam tari tradisi Jawa seperti pola lantai montor mabur dan jejer wayang, gerak-gerak yang 


\section{GE[AR Jumal sori Budsya}

mengembangkan motif gerak tari tradisi putri, dan penggunaan alat musik kemanak.

Terdapat hubungan yang terkait antara tari bedhaya dengan Bedhaya Sarpa Rodra dalam aspek koreografinya. Sehingga dapat dikatakan sebagai garap "bedhayan", artinya bahwa proses penyusunannya meniru atau terinspirasi oleh garap tari genre bedhaya tradisi.

\section{Catatan Akhir:}

${ }^{1}$ Ratu gung binathara adalah bentuk kekuasaan raja yang berisi pemeliharaan hukum, penguasa dunia, dan penentu kebijakan.

${ }^{2}$ Sipatan adalah bentuk rias mata yang ditarik ke atas.

${ }^{3}$ Eyeshadow adalah warna rias pada kelopak mata.

\section{KEPUSTAKAAN}

Dewi, Nora Kunstantina. "Tari Bedhaya Ketawang:

Reaktualisasi Hubungan Mistis

Panembahan Senopati dengan Kanjeng

Ratu Kencana Sari dan Perkembangannya."

Tesis S2 Pengkajian Seni Pertunjukan Universitas Gadjah Mada, 1994.

Hadiwidjojo, K.G.P.H. Bedhaya Ketawang. Jakarta: PN.Balai Pustaka,1981.

Hadi, Y.Sumandiyo. Aspek-aspek Dasar Koreografi Kelompok. Yogyakarta: ELKHAPI, 2003.

Morris, Desmon. People Watching: the Desmon Morris Guide to Body Language. Great Britain: Bookmarque Ltd, Croydon, Surrey, 2002.

Prihartini, Nanik Sri. IImu Tari Joged Tradisi Gaya Kasunanan Surakarta. Surakarta: ISI Press, 2007.
Suharti, Theresia. "Penari Wanita Keraton Dulu dan Kini". SENI,Jurnal Pengetahuan dan Penciptaan Seni. Vol. 7, No. 4 (April 2000): 295-305.

Bedhaya Semang Karaton Ngayogyakarta Hadiningrat Reaktualisasi Sebuah Tari Pusaka. Yogyakarta: PT.Kanisius, 2015.

\section{Narasumber:}

1. Saryuni Padminingsih (57), penyusun tari Bedhaya Sarpa Rodra. Jl. Garuda No 17 Perum UNS 1V Triyagan, Mojolaban, Sukoharjo.

2. Didik Bambang Wahyudi (55), dosen ISI Surakarta. Semanggi RT 01 RW 11, Pasar Kliwon, Surakarta.

3. Wahyu Santoso Prabowo (63), dosen ISI Surakarta. Perumahan Mojosongo Pratama No B9 Sabrang Kulon, Mojosongo, Jebres, Surakarta.

4. Dedek Wahyudi (55), penyusun musik tari Bedhaya Sarpa Rodra. Jl. Petruk Block G No 19 RT 05 RW 22, Ngringo Indah, Jaten, Karanganyar.

5. Agus Tasman (79), seniman tari. Karangasem, RT 02 RW 03, Laweyan, Surakarta.

6. Silverter Pamardi (57), dosen ISI Surakarta. JI. Garuda No

17 Perum UNS 1V Triyagan, Mojolaban, Sukoharjo.

7. Surni (33 ), penari Bedhaya Sarpa Rodra. JI. MH. Thamrin no 9B, Manahan.

8. Supriyadi (39), penata lampu tari Bedhaya Sarpa Rodra. Jl. Teratai No 16, Perum Sapen Raya, Mojolaban, Sukoharjo. 